\title{
FORMULASI MIKROPARTIKEL BERPORI DALAM POLI (D,L-Laktida) SEBAGAI SCAFFOLDDENGAN TEKNIK EMULSIFIKASI PENGUAPAN PELARUT
}

\author{
Lili Fitriani', Tri Suciati ${ }^{2}$ \\ ${ }^{1}$ Fak Farmasi Universitas Andalas \\ ${ }^{2}$ Sekolah Farmasi Institut Teknologi Bandung
}

\begin{abstract}
Poly (D,L-lactide acid) has been used as scaffold for tissue engineering. In this study, $\mathrm{P}_{\mathrm{DL}} \mathrm{LA}$ microparticles were made into porous microparticles. Porous microparticles were proposed to reduce burst release of protein and to prevent diffusion of released protein into non-target tissue. Formulation of porous microparticles was made by water-oil-water $\left(\mathrm{W}_{1} / \mathrm{O} / \mathrm{W}_{2}\right)$ emulsification-solvent evaporation using gas foamed as porogen. Variations of the amount of sodium bicarbonate, volume of citric acid solution and time for homogenization were optimized to produce optimum formulation. Evaluation for this microparticles included morphology of particles, particle size distribution and porosity. Porous microparticle produced by ratio volume of acid : dichloromethane : poly(vynil alcohol) (PVA) = 1:3:3 and the ratio of sodium bicarbonate $: \mathrm{P}_{\mathrm{DL}} \mathrm{LA}=2: 3$ was the optimum formulation.
\end{abstract}

Keywords :Porous Microparticles, $P_{D L} L A$, Gas Foamed, Scaffold, Solvent Evaporation

\section{PENDAHULUAN}

Polimer biodegradabel telah banyak digunakan untuk membentuk scaffold berpori untuk proses regenerasi jaringan. Stuktur open porous dengan interkoneksi pori yang baik dalam scaffold dibutuhkan tidak hanya untuk mengakomodasi sel dalam jumlah yang cukup tetapi juga untuk memfasilitasi transport nutrisi dan oksigen ${ }^{[1,2]}$. $\mathrm{P}_{\mathrm{DL}} \mathrm{LA}$ telah digunakan untuk pembentukkan biodegradabel scaffold karena kemampuan biodegradasi yang terkontrol dan biokompatibilitas yang baik ${ }^{[3,4,5]}$.

Scaffold merupakan matriks ekstraselular buatan yang digunakan untuk menyediakan struktur tiga dimensi yang akan menggantikan fungsi matriks ekstraselular alami sampai sel dapat memebentuk matriks baru ${ }^{[6]}$. Pembuatan scaffold untuk rekayasa jaringan mempunyai kriteria yang meliputi : (1) bahan yang digunakan bersifat biokompatibel, biodegradabel dengan kecepatan degradasi yang terkontrol dan dapat dibuat dalam bentuk tiga dimensi dalam berbagai bentuk dan ukuran. (2) mempunyai porositas yang tinggi dengan pori tersebar merata dan mempunyai interkoneksi. (3) mempunyai kekuatan mekanik sehingga dapat menahan gaya kontraktil sel dan aliran dalam tubuh ${ }^{[7,8]}$.

Metode yang paling umum digunakan untuk pembentukan scaffold berpori yaitu porogen leaching menggunakan garam-garam, karbohidrat, malam hidrokarbon, yang ditambahkan pada campuran polimer atau pelarut dan kemudian dicuci setelah penguapan pelarut untuk pembentukan pori. Metode lain yang dapat digunakan diantaranya yaitu emulsi / freeze drying dan ekspansi dalam cairan superkritikal. Perbandingan berbagai metode yang digunakan untuk pembuatan mikropartikel berpori dapat dilihat dari Tabel 1. 
Tabel 1. Berbagai Metode Pembentukkan Scaffold Berpori ${ }^{[8]}$

\begin{tabular}{|c|c|c|c|}
\hline Metode & $\begin{array}{c}\text { Porositas } \\
(\%)\end{array}$ & Karakteristik scaffold & $\begin{array}{c}\text { Ukuran pori } \\
(\mu \mathrm{m})\end{array}$ \\
\hline Fiber Bonding & 81 & 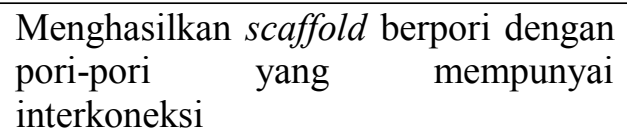 & 500 \\
\hline $\begin{array}{l}\text { Solvent casting / } \\
\text { particulate } \\
\text { leaching }\end{array}$ & 87 & $\begin{array}{l}\text { Struktur mempunyai kekuatan cukup } \\
\text { baik }\end{array}$ & 100 \\
\hline Gas foaming & 93 & Biokompatibel & 100 \\
\hline $\begin{array}{l}\text { Microparticle- } \\
\text { based scaffold }\end{array}$ & 70 & $\begin{array}{l}\text { Mempunyai pori yang terinterkoneksi, } \\
\text { sistem penghantaran protein }\end{array}$ & 100 \\
\hline $\begin{array}{l}\text { Pemisahan fasa / } \\
\text { emulsifikasi }\end{array}$ & 95 & $\begin{array}{l}\text { Ukuran pori dan porositas dapat } \\
\text { diubah dengan mudah }\end{array}$ & $13-35$ \\
\hline
\end{tabular}

Garam efervesen seperti ammonium bikarbonat dapat digunakan sebagai garam porogen yang menghasilkan gas. Ammonia dan karbondioksida menghasilkan open porous dalam jumlah besar untuk mengakomodasi sel dengan kerapatan yang tinggi sehingga mempercepat pertumbuhan sel dengan memfasilitasi transport nutrisi dan oksigen. Scaffold berpori yang dibuat untuk implantasi baik ukuran maupun bentuk harus disesuaikan dengan bentuk jaringan yang rusak. ${ }^{[9,10]}$.

Scaffold berpori juga dapat dibentuk dari mikropartikel dengan penggunaan pemanasan atau plastisisasi menggunakan gas karbondioksida sub-kritik. Pembuatan scaffold dengan menggunakan pemanasan dimana rantai polimer pada permukaan mikropartikel akan bergerak sesuai dengan kenaikan suhu yang selanjutnya akan bergabung dengan mikropartikel lain pada titik kontak sehingga membentuk struktur tiga dimensi. Selama proses pendinginan rantai polimer bergerak dengan lambat dan struktur polimer akan tertahan menjadi bentuk padat ketika matriks mencapai kekuatan tertentu. Parameter yang mempengaruhi pembentukkan ikatan antarmuka meliputi waktu, suhu, tekanan dan berat molekul polimer ${ }^{[11]}$.

\section{METODOLOGI PENELITIAN}

\section{Bahan}

PDLAA (Purac, PDL 05), PVA 88\% hydrolized (Sigma Aldrich), natrium bikarbonat $\left(\mathrm{NaHCO}_{3}\right)$ (Merck), asam sitrat (Merck), tablet PBS (posfat buffer saline) $\mathrm{pH}$ 7,4 (Biobasic), air suling, pereaksi Bradford (Sigma Aldrich), metilen klorida (Merck), Pluronic F127 (BASF), natrium alginat.

\begin{abstract}
Alat
Vorteks (IKA), pengaduk magnet, scanning electron microscope (SEM) (Jeol JSM 6360 LA), Hitachi TM 1000, freeze dryer, sentrifuga (Hettich EBA 8S), ayakan, serta alat-alat gelas yang umum digunakan di laboratorium.

\section{Persiapan}

Mikropartikel berpori dibuat dengan dengan emulsifikasi penguapan pelarut $\mathrm{A}_{1} / \mathrm{M} / \mathrm{A}_{2}$ menggunakan natrium bikarbonat dan larutan asam sitrat sebagai pembentuk gas yang menghasilkan pori-pori dalam mikropartikel.Formulasi mikropartikel berpori dapat dilihat dari Tabel 2.
\end{abstract}


Tabel 2. Formula Mikropartikel Berpori

\begin{tabular}{ccccc}
\hline Formula & $\begin{array}{c}\text { Rasio } \\
\mathrm{a}_{1} / \mathrm{m} / \mathrm{a}_{2}\end{array}$ & $\begin{array}{c}\text { Serbuk } \\
\mathrm{NaHCO}_{3}(\mathrm{mg})\end{array}$ & $\begin{array}{c}\text { Konsentrasi dan volum } \\
\text { larutan asam sitrat }(\%, \mu \mathrm{L})\end{array}$ & $\begin{array}{c}\text { Waktu homogenisasi } \\
\text { emulsi primer (detik) }\end{array}$ \\
\hline F I & $1: 5: 5$ & 200 & $5 ; 300$ & 10 \\
F II & $1: 5: 5$ & 150 & $5 ; 300$ & 10 \\
F III & $1: 5: 5$ & 100 & $5 ; 300$ & 10 \\
F IV & $1: 5: 5$ & 200 & $5 ; 300$ & 20 \\
F V & $1: 5: 5$ & 200 & 7,$5 ; 300$ & 20 \\
F VI & $1: 5: 5$ & 250 & $5 ; 300$ & 20 \\
F VII & $1: 3: 3$ & 200 & $5 ; 500$ & 20 \\
F VIII & $1: 3: 3$ & 250 & $5 ; 500$ & 20 \\
F IX & $1: 3: 3$ & 333 & $5 ; 500$ & 20 \\
\hline
\end{tabular}

Pembuatan mikropartikel berpori yaitu sejumlah tertentu serbuk natrium bikarbonat dicampur ke dalam 0,5 g $P_{\mathrm{DL}} \mathrm{LA}$ dalam $1,5 \mathrm{~mL}$ metilen klorida (fasa $\mathrm{M}$ ), diaduk dengan vorteks kecepatan skala 4 selama 2 menit 30 detik, dan ditambahkan larutan asam sitrat (fasa $A_{1}$ ) dan diaduk dengan kecepatan vorteks skala 3 selama 10 sampai 20 detik, sehingga menghasilkan gas karbondioksida. Fasa luar (fasa $\mathrm{A}_{2}$ ), 1,5 mL PVA $0,3 \%$, ditambahkan dan diaduk dengan kecepatan vorteks skala 3 selama 20 detik. Selanjutnya emulsi dituang dalam 48,5 mL larutan PVA $0,3 \%$ dan dilakukan penguapan pelarut serta pengerasan mikropartikel selama 4 jam dalam lemari asam. Mikropartikel yang terbentuk kemudian disaring dan dikeringkan dengan teknik pengeringan beku.

\section{Evaluasi mikropartikel berpori}

a. Morfologi mikropartikel berpori

Pemeriksaan morfologi mikropartikel berpori dilakukan dengan menggunakan mikroskop elektron (SEM).Sampel mikropartikel dilapisi dengan "gold-paladium" sesuai dengan prosedur standar untuk pengukuran menggunakan SEM dan diamati di bawah mikroskop elektron dengan perbesaran tertentu.

b. Distribusi ukuran mikropartikel

Penentuan distribusi ukuran partikel dilakukan dengan menggunakan ayakan dengan diameter lubang yang berbeda-beda (100, 280, dan 400 $\mu \mathrm{m})$. Mikropartikel dari tiap fraksi dikumpulkan dan ditimbang kemudian ditentukan presentase bobot tiap fraksi terhadap bobot total mikropartikel yang diperoleh.

c. Porositas mikropartikel

Penentuan porositas mikropartikel berpori dilakukan dengan menentukan bobot jenis untuk formula optimum yang dibandingkan dengan mikropartikel tidak berpori.Selanjutnya dilakukan perhitungan water uptake ratio dimanasejumlah tertentu mikropartikel dibasahi dengan alkohol 95\% dan dicuci dengan air suling sebanyak 3 kali, selanjutnya diinkubasi dalam larutan bufer posfat selama 8 jam. ${ }^{11}$ Kandungan air diukur dengan menimbang mikropartikel basah dengan mikropartikel kering, dimana kelebihan air pada permukaan mikropartikel dibuang.

Water up take ratio $=\left(\mathrm{M}_{\mathrm{b}}-\mathrm{M}_{\mathrm{k}}\right) / \mathrm{M}_{\mathrm{k}} \times 100 \%$

Keterangan : $\mathrm{Mb}=$ berat mikropartikel basah $\mathrm{Mk}=$ berat mikropartikel kering

Porositas total mikropartikel ditentukan menggunakan persamaan ${ }^{11}$ :

\begin{tabular}{r}
\hline$P_{\text {total }}=\left(1-\left(\rho_{\text {geometrik }} \rho_{\text {mikropartikel }}\right)\right) \times 100$ \\
Keterangan $: \rho_{\text {geometrik }}=$ bobot jenis nyata dari \\
total mikropartikel \\
$\rho$ mikropartikel $=$ bobot jenis nyata \\
untuk poli $(\mathrm{D}$, L-laktida $)$ adalah \\
$1,25 \mathrm{~g} / \mathrm{mL}^{3}$
\end{tabular}




\section{HASIL DAN PEMBAHASAN}

Pembuatan mikropartikel berpori dilakukan dengan emulsifikasi penguapan pelarut $\mathrm{A}_{1} / \mathrm{M} / \mathrm{A}_{2}$.Diteliti faktor-faktor yang dapat mempengaruhi karakteristik mikropartikel berpori yaitu rasio $A_{1} / \mathrm{M} / \mathrm{A}_{2}$, jumlah natrium bikarbonat, waktu kontak fasa $\mathrm{A}_{1}$ dengan fasa $\mathrm{M}$ dan konsentrasi asam sitrat.Kecepatan vorteks pada saat pencampuran asam sitrat dalam campuran $\mathrm{P}_{\mathrm{DL}} \mathrm{LA}$-natrium bikarbonat dalam metilen klorida dan kecepatan vorteks pada penambahan fasa luar menjadi titik kritis dalam pembuatan mikropartikel berpori.

Tahap awal proses pembuatan mikropartikel berpori dilakukan dengan menggunakan rasio fasa $A_{1} / M / A_{2}=1: 5: 5$. Perbandingan rasio ini merupakan perbandingan yang umum digunakan untuk pembuatan mikropartikel dengan metode $\mathrm{A}_{1} / \mathrm{M} / \mathrm{A}_{2}$. Pengamatan mikroskopik pada Gambar 4.1 menunjukkan bahwa mikropartikel yang terbentuk mempunyai pori pada F I, F II dan F III, namun ukuran pori untuk setiap mikropartikel dalam satu formula berbeda. Hal ini kemungkinan disebabkan karena waktu kontak antara fasa $A_{1}$ dengan minyak yang terlalu singkat sehingga menyebabkan serbuk natrium bikarbonat tidak bereaksi sempurna dengan asam sitrat dan gelembung gas yang dihasilkan tidak merata mengakibatkan pori yang terbentuk tidak akan sama.

Pada F IV, F V dan F VI jumlah natrium bikarbonat yang ditambahkan pada fasa minyak dinaikkan dan waktu kontak antara fasa air 1 dengan minyak ditingkatkan dari 10 detik menjadi 20 detik. Penambahan jumlah nartium bikarbonat akan berpengaruh terhadap jumlah pori yang terbentuk, karena semakin banyak natrium bikarbonat yang ada dalam fasa minyak maka gelembung gas yang akan dihasilkan ketika direaksikan dengan larutan asam sitrat akan semakin banyak sehingga jumlah pori yang terbentuk akan semakin besar. Pengaruh konsentrasi asam sitrat juga diamati pada pembuatan mikropartikel ini. Konsentrasi asam sitrat pada $\mathrm{F} V$ dinaikkan menjadi $7,5 \%$ dan dibandingkan dengan konsentrasi asam sitrat pada F IV yaitu 5\%. Dari ketiga formula yang tersebut pengaruh penambahan natrium bikarbonat secara umum meningkatkan jumah pori. Pengaruh penambahan waktu kontak antara fasa airl dengan fasa minyak menghasilkan mikropartikel dengan pori yang lebih tersebar merata dan ukuran pori yang hampir sama yang bisa dilihat pada gambar 1, sehingga 20 detik merupakan waktu yang optimum untuk pembuatan mikropartikel. Peningkatan konsentrasi asam sitrat tidak memberikan pengaruh yang berarti terhadap ukuran pori mikropartikel yang terbentuk yang dapat dilihat dari Gambar 1.

Rasio antara $\mathrm{A}_{1} / \mathrm{M} / \mathrm{A}_{2}$ secara teoritis mempengaruhi ukuran pori yang akan terbentuk sehingga pembuatan mikropartikel selanjutnya dilakukan dengan perbandingan $\mathrm{A}_{1} / \mathrm{M} / \mathrm{A}_{2}=1: 3: 3$. Dari F VII, F VIII, dan F IX diperoleh kondisi yang optimum untuk menghasilkan mikropartikel berpori dengan ukuran pori yang diharapkan. Dari Gambar 1 dapat diamati untuk F VII, mikropartikel yang terbentuk mempunyai pori yang lebih kecil dibandingkan dengan $\mathrm{F}$ VIII dan F IX. Pori yang terbentuk pada F IX mempunyai ukuran pori yang cukup besar pada permukaan mikropartikel yaitu $\pm 20 \mu \mathrm{m}$ yang sesuai dengan ukuran pori yang diharapkan.

Ukuran mikropartikel dipengaruhi oleh kecepatan pengadukan yang dilakukan pada saat pembentukkan globul dimana tahap pembentukkan globul terjadi pada saat penambahan larutan PVA.Pada percobaan yang tidak dilakukan variasi kecepatan vorteks pada penambahan fasa luar. Dari Gambar 2, ukuran mikropartikel yang diperoleh sebagian besar berkisar dalam rentang yang diinginkan yaitu 100-280 $\mu \mathrm{m}$. Sebagian besar partikel lain berada pada rentang $280-400 \mu \mathrm{m}$ dan sisa mikropartikel yaitu berukuran lebih besar $400 \mu \mathrm{m}$ dan lebih kecil $100 \mu \mathrm{m}$. Hal ini berarti ukuran yang diharapkan dalam formulasi mikropartikel berpori dapat diperoleh dengan kecepatan homogenisasi pada kondisi optimum. 


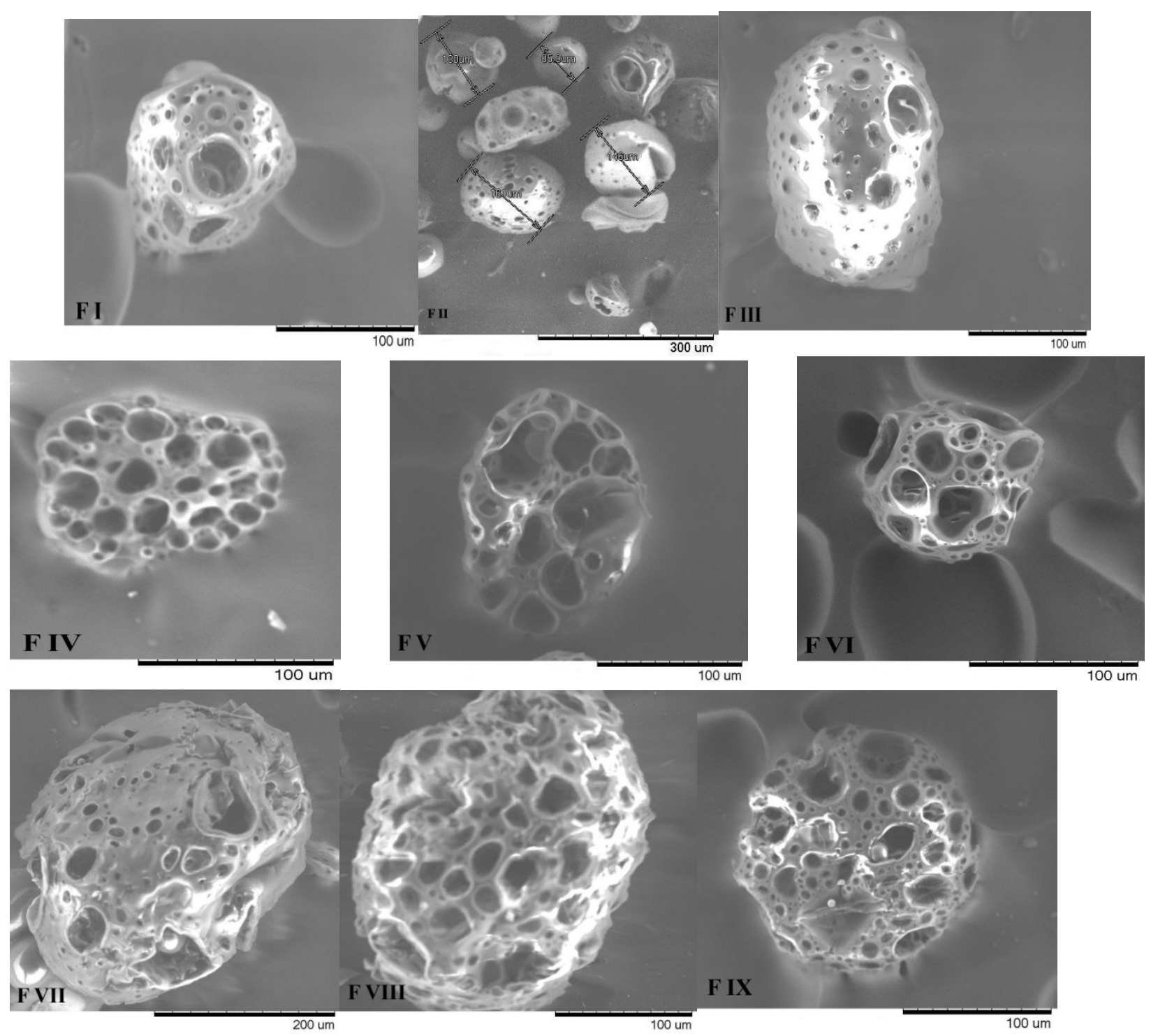

Gambar 1. Morfologi mikropartikel berpori berbagai formuladiukur menggunakan Hitachi TM 1000 (Formula I, III, IV, V, VI, VIII, IX dengan skala $100 \mu \mathrm{m}$; formula II dengan skala $200 \mu \mathrm{m}$; dan formula VII dengan skala $200 \mu \mathrm{m})$ 


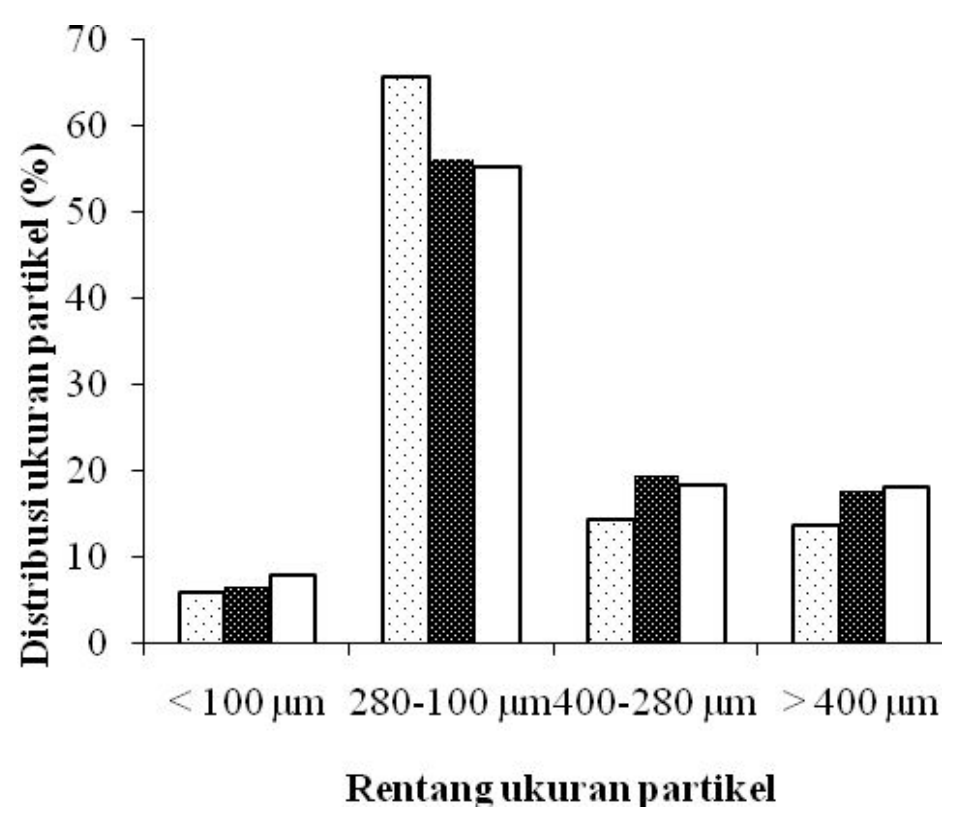

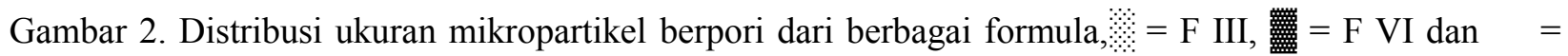
FIX

Penentuan porositas dari mikropartikel berpori dilakukan dengan pemeriksaan bobot jenis mikropartikel berpori dari formula optimum yang dibandingkan dengan mikropartikel tidak berpori.Dari percobaan yang dilakukan, penentuan hasil bobot jenis mikropartikel berpori sesuai dengan teori dimana mikropartikel berpori mempunyai bobot jenis yang lebih kecil dibanding mikropartikel tidak berpori (Gambar 3).

Perhitungan porositas selanjutnya dilakukan dengan penentuan porositas total dan water uptake ratio yang dapat digunakan sebagai perkiraan porositas dalam skala laboratorium. Prinsip penentuan porositas dengan cara ini yaitu berdasarkan kemampuan mikropartikel untuk menyerap air ke dalam pori-pori. Hasil penentuan porositas dapat dilihat dari Gambar 3.
Porositas total ditentukan untuk mikropartikel berpori dari formula optimum dengan mikropartikel tidak berpori. Porositas total mikropartikel tidak berpori yaitu $73,54 \%$ dan mikropartikel berpori adalah 93,54\%. Hal ini menunjukkan bahwa mikropartikel berpori telah mempunyai pori yang cukup banyak.

Hasil penentuan water uptake ratio untuk mikropartikel berpori F III, F VI dan FIX menunjukkan adanya perbedaan dimana nilai yang diperoleh meningkat sesuai dengan formulasi jumlah serbuk natruium bikarbonat dan larutan asam sitrat yang ditambahkan untuk membentuk pori-pori. 


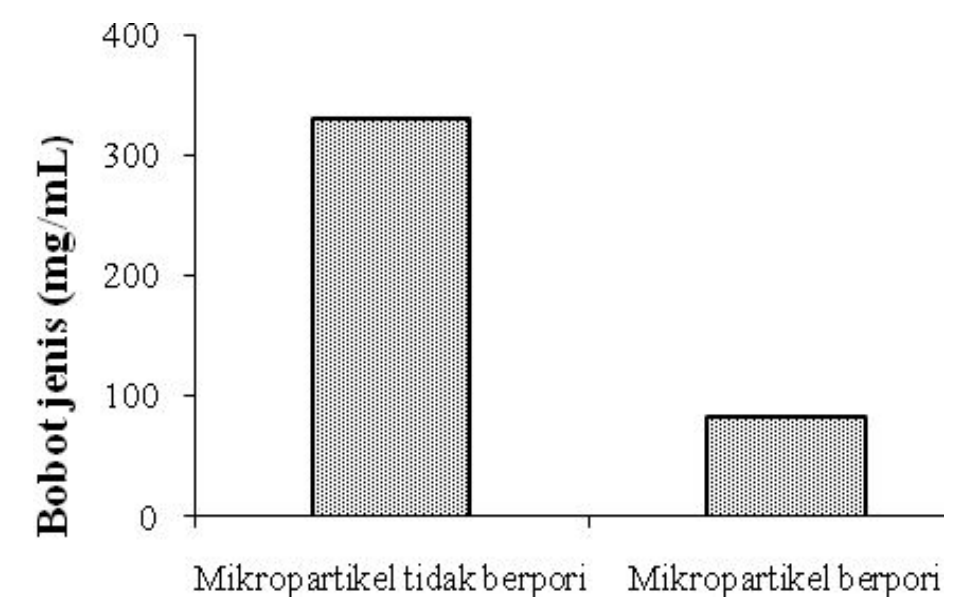

Gambar 3. Bobot jenis mikropartikel tidak berpori dan mikropartikel berpori

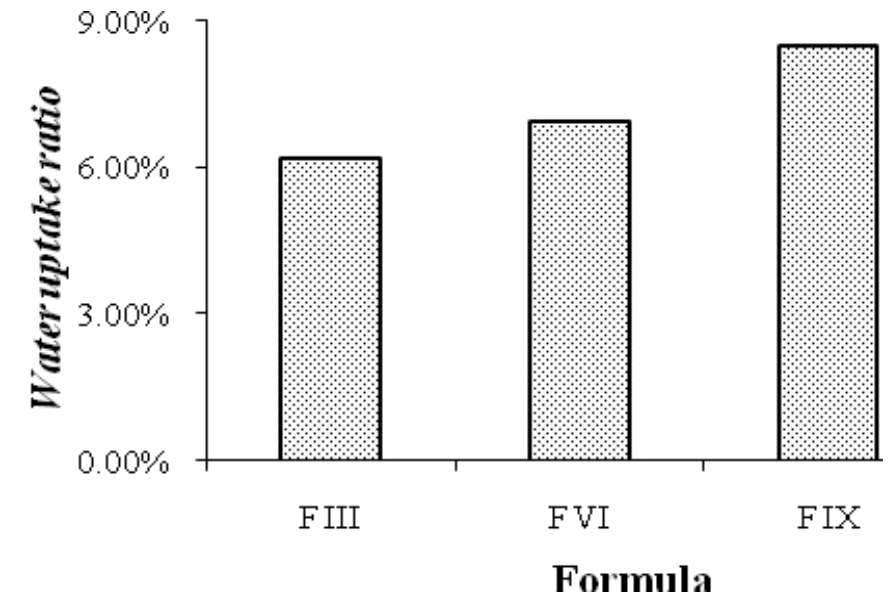

Gambar 4. Hasil penentuan water uptake ratiountuk mikropartikel berpori

\section{KESIMPULAN}

Formulasi mikropartikel berpori dapat dibuat menggunakan reaksi efervesen yang menghasilkan gelembung gas karbondioksida dengan metode emulsifikasi penguapan pelarut. Formulasi mikropartikel berpori terbaik diperoleh dengan perbandingan volum larutan asam sitrat : metilen klorida : PVA $0,3 \%=1: 3: 3$ dan perbandingan natrium bikarbonat: PLA $=2: 3$.

\section{DAFTAR PUSTAKA}

1. J. M. Anderson, M. S. Matthew, Biodegradation and Biocompatibility of PLA and PLGA Microspheres, Drug Delivery, 28, 5-24 (1997)

2. B. Dieter, Chemical Synthesis of Polylactide and its Copolymer for Medical Applications, Polymer Degradation and Stability, 129-135 (1998).

3. R. C. Rowe, Handbook of Pharmaceutical Excipients, $4^{\text {th }}$ ed., Pharmaceutical Press and 
American Pharmacists Association, London, 19-24 (2003).

4. Y. S. Nam, J. J. Yoon, andT. G. Park, A Novel Fabrication of Macroporous Biodegradable Polymer Scaffold Using Gas Foaming Salt as a Porogen Additive, Macroporous Biodegradable Polymer Scaffold, 1-7 (1999).

5. S. K. Sahoo, A. K. Panda, andV. Labhasetwar, Characterization of Porous PLGA/PLA Microparticles as a Scaffold for Three Dimensional Growth of Breast Cancel Cells, Biomacromolecules, 6, 1132-1139 (2005).

6. A.Vacanti and C. P. Vacanti, The History and Scope of Tissue Engineering in Principles of Tissue engineering (eds Lanza RP, Langer R, Vacanti J) 2ed., 3-7 (2000).

7. S. Jacobsen, PH. Degée, H. G. Fritz, PH. Dubois, andR. Jérome, Polylacide (PLA)-A New Way of Production, Polymer Engineering and Science, 39(7), 1311-1319 (1999).
8. C. T. Buckleyand K. U. O'Kelly, Regular Scaffold Fabrication Techniques for Investigations in Tissue Engineering, BioMechanical Engineering, 147-166 (2004).

9. T. K. Kim, J. J. Yoon, D. S. Lee, and T. G Park, Gas Foamed Open Porous Biodegradable Polymeric Microspheres, Biomaterials, 27, 152-159 (2006).

10.H. K. Kim H. J. Chung, andT. G. Park, Biodegradable Polymeric Microspheres with "open/closed" Pores for Sustained Release of Human Growth Hormone, Journal of Controlled Release, 112, 164-174 2006).

11.T. Suciati, F. R. A. J. Rose, and K. M. Shakesheff,. Development of a microparticlebased scaffold for tissue engineering, British Society for Matrix Biology and UK Tissue and Cell Engineering Society (2004). 